\title{
Harnessing B cells in immunotherapy
}

\author{
"...the functions of B cells that might determine the \\ direction and impact of innate, cellular and humoral \\ immunity in infection, cancer and transplantation."
}
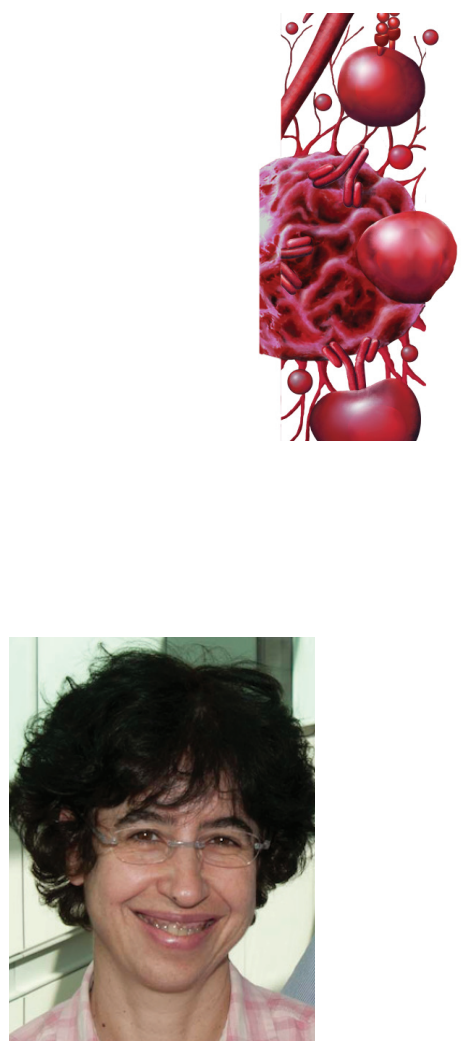

Marilia Cascalho Departments of Surgery \& Microbiology \& Immunology, University of Michigan, Ann Arbor, MI, USA

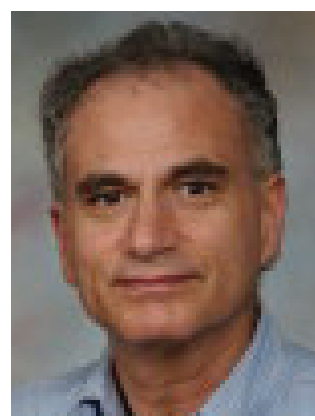

Jeffrey L Platt

Author for correspondence:

Departments of Surgery \& Microbiology \& Immunology, University of Michigan, Ann Arbor, MI, USA

Tel.: +1 7346157755

Fax: +17346157141

plattj|@umich.edu denote the apparent change in the transplanted organ that rendered it less susceptible to antibody-mediated rejection [3]. Since then, accommodation or a condition quite like it has been observed not only in transplants but also in tumors, infection, injury and inflammation [4]. Clearly, if one wishes to marshal immunity and inflammation toward the destruction of a tumor or cells harboring a latent virus, one should consider to subtoxic ischemia or putative agonists of ischemic injury can reduce the severity of or even prevent severe injury when ischemia of greater severity is inflicted in the laboratory. Yet, putting this concept to clinical use has proven challenging, at least in part because one cannot know a priori how much ischemia or agents of ischemic injury such as intracellular $\mathrm{Ca}^{++}$are needed to induce protection and how much will instead induce a level of injury to which the subsequent ischemic insult will add. For this reason, we have been keen to see if accommodation can be deliberately induced to avoid injury in transplants
Future fss 
and suppressed to make tumors more susceptible to immunotherapy, chemotherapy or irradiation.

We believe that $\mathrm{B}$ cells might offer a system for discovery of mechanisms of accommodation pertinent to tumors and transplants. B cells are exposed to 'genetic stress' during recombination of immunoglobulin variable and constant regions and during somatic hypermutation. A fuller understanding of how B cells survive these events might offer clues to mechanisms that could be attacked in tumors. B cells are also exposed to environmental challenges, including bacterial products in the gut and splanchnic circulation and to hypoxia in lymphoid tissues. These conditions potentially model challenges confronted by tumors and transplants. B cells thus struggle, quite successfully, to survive these assaults $[8,9]$. We hope that understanding how B cells so reliably and 'safely' resist genotoxicity and hypoxia will provide clues about how similar responses can be generated in transplants and injured tissues and suppressed in tumors.

\section{"...we have been keen to see if accommodation can be deliberately induced to avoid injury in transplants and suppressed to make tumors more susceptible to immunotherapy..."}

Because the preponderance of antibodies and complement reside in the blood and not in extravascular spaces, antibodies appear to have the most profound impact on organ transplants, leukemias and bloodborne microorganisms and much less or no impact on transplants, tumors and microorganisms residing outside of blood vessels [10]. In fact, paradoxically, $\mathrm{B}$ cells and antibodies sometimes appear to inhibit effector responses, especially extravascular targets. In some cases, the 'protective' impact of antibodies simply reflects a correlation with the functions of regulatory $\mathrm{B}$ cells, the properties of which have been reviewed in detail elsewhere [11]. However, there are three other ways that antibodies might directly protect immune targets. First, antibodies that diffuse into extravascular spaces might induce accommodation rather than cytotoxicity because after antibody binds, the low, sublytic concentrations of complement in those spaces induce resistance to cytotoxicity [12]. Second, B cells and their products, including antibodies, can directly nurture tumor growth [13] and tumor-specific antibodies might bind to cellular antigens blocking cellular immune responses [14]. Small amounts of complement activated in the vicinity of tumors likewise can exert a trophic effect [15]. The ability of B cells and their products to protect tumors (and transplants) and promote growth is called 'enhancement'. Enhancement of tumor transplants was once a subject of intense interest, and we think renewed inquiry, focused especially on prevent- ing immune therapeutics from enhancing tumors or infected cells, might increase efficacy. Third, some antibodies, especially certain natural antibodies, can have a direct, protective or reparative impact on cellular targets [16]. How these antibodies, some encoded by germline immunoglobulin variable regions, change the biological responses of cellular targets is poorly understood but one can envision advancing immunotherapies by providing these antibodies in some setting and inhibiting their binding in others.

Two other facets of B-cell responses that might determine whether or not protective immunity or accommodation ensues are the kinetics and the breadth of the response. We glimpsed the potential importance of the kinetics of the B-cell responses in some counter-intuitive observations in mice. To explore the involvement of transmembrane activator and calcium-modulating cyclophilin ligand interactor, or TACI, in host defense we compared the ability of TACI-deficient and wildtype to clear Citrobacter rodentium from the gut. We had previously found that TACI promotes B-cell maturation $[8,17]$ and that deficiency of TACI in mice and humans is associated with low-immunoglobulin levels in blood and the common variable immunodeficiency syndrome. Since clearance of $C$. rodentium depends absolutely on B-cell responses, we expected that mice lacking TACI, like immunodeficient mice, would succumb to infection. However, instead we found that while TACI-deficient mice, despite being 'immunodeficient' by most measures, produce a rapid burst of highaffinity $\operatorname{IgG}$ after infection and this $\operatorname{IgG}$ enables the mice to clear the organism more effectively than wildtype mice (which produce more antibody but do so gradually and in a greater range of affinities) [17]. These results suggest the kinetics and focus of B-cell responses can have as great an impact on host defense as the total amount of antibody produced. We are eager to see how broadly applicable these observations will prove to be.

We would offer one final comment on the harnessing of B-cell responses for immunotherapy. As we have briefly reviewed above and elsewhere $[1,18,19]$, B-cell functions extend well beyond the production of antibodies, and touch on nearly every aspect of innate and adaptive immunity, including development of lymphoid organs and of $\mathrm{T}$ cells, antigen presentation, regulation of $\mathrm{T}$-cell activation and effector functions. B-cell functions can also determine the impact immunity will have on the target cell or microorganism. Although antibody concentration, isotype, avidity, cytotoxicity or virus neutralization continue to serve as standards for evaluating vaccines and assessing host responses to infection and transplantation, these approaches should not be assumed to represent the spectrum of B-cell responses much less the impact 
those responses might have. In populations of transplant recipients, the presence, level and specificity of antibodies against the graft donor may correlate the outcome but in individual subjects, these indices alone mean little. Therefore, we believe the development of new approaches to evaluating the range of B-cell responses will prove pivotal to the harnessing of those responses for the treatment of disease.

\section{References}

1 Cascalho MI, Chen BJ, Kain M, Platt JL. The paradoxical functions of B cells and antibodies in transplantation. J. Immunol. 190(3), 875-879 (2013).

2 Bannett AD, Mcalack RF, Morris M, Chopek M, Platt JL. ABO incompatible renal transplantation: a qualitative analysis of native endothelial tissue $\mathrm{ABO}$ antigens after transplant. Transplant. Proc. 21, 783-785 (1989).

3 Platt JL, Vercellotti GM, Dalmasso AP et al. Transplantation of discordant xenografts: a review of progress. Immunol. Today 11, 450-456 (1990).

4 Koch CA, Khalpey ZI, Platt JL. Accommodation: preventing injury in transplantation and disease. J. Immunol. 172(9), 5143-5148 (2004).

5 Platt JL, Nath KA. Heme oxygenase: protective gene or Trojan horse. Nat. Med. 4(12), 1364-1365 (1998).

6 Ferdinandy P, Hausenloy DJ, Heusch G, Baxter GF, Schulz R. Interaction of risk factors, comorbidities, and comedications with ischemia/reperfusion injury and cardioprotection by preconditioning, postconditioning, and remote conditioning. Pharmacol. Rev. 66(4), 1142-1174 (2014).

7 Heyman SN, Leibowitz D, Mor-Yosef Levi I et al. Adaptive response to hypoxia and remote ischemia preconditioning: a new HIF era in clinical medicine. Acta Physiol. (Oxf.) doi:10.1111/apha.12613 (2015) (Epub ahead of print).

8 Tsuji S, Cortesão C, Bram R, Platt JL, Cascalho M. TACI deficiency impairs sustained Blimp-1 expression in B cells decreasing long-lived plasma cells in the bone marrow. Blood 118(22), 5832-5839 (2011).

\section{Financial \& competing interests disclosure}

The authors' work was supported by the NIH. The authors have no other relevant affiliations or financial involvement with any organization or entity with a financial interest in or financial conflict with the subject matter or materials discussed in the manuscript apart from those disclosed.

No writing assistance was utilized in the production of this manuscript.

9 Geraldes P, Rebrovich M, Herrmann K et al. Ig heavy chain promotes mature $\mathrm{B}$ cell survival in the absence of light chain. J. Immunol. 179, 1659-1668 (2007).

10 Cascalho M, Platt JL. The immunological barrier to xenotransplantation. Immunity 14, 437-446 (2001).

11 Tedder TF. B10 cells: a functionally defined regulatory B cell subset. J. Immunol. 194(4), 1395-1401 (2015).

12 Reiter Y, Ciobotariu A, Fishelson Z. Sublytic complement attack protects tumor cells from lytic doses of antibody and complement. Eur. J. Immunol. 22, 1207-1213 (1992).

13 Schreiber H, Wu TH, Nachman J, Rowley DA. Immunological enhancement of primary tumor development and its prevention. Semin. Cancer Biol. 10(5), 351-357 (2000).

14 Snell GD, Winn HJ, Stimpfling JH, Parker SJ. Depression by antibody of the immune response to homografts and its role in immunological enhancement. J. Exp. Med. 112(2), 293-314 (1960).

15 Pio R, Corrales L, Lambris JD. The role of complement in tumor growth. Adv. Exp. Med. Biol. 772, 229-262 (2014).

16 Platt JL, Cascalho M. IgM in the kidney: a multiple personality disorder. Kidney Int. 88(3), 439-441 (2015).

17 Tsuji S, Stein L, Kamada N et al. TACI deficiency enhances antibody avidity and clearance of an intestinal pathogen. J. Clin. Invest. 124(11), 4857-4866 (2014).

18 Cascalho M, Platt JL. Novel functions of B cells. Crit. Rev. Immunol. 27(2), 141-151 (2007).

19 Platt JL, Tsuji S, Cascalho M. Novel functions of B cells in transplantation. Curr. Opin. Organ Transplant. 16(1), 61-68 (2011). 